\title{
Cognitive Study for Language as a Complex Adaptive System: Evidence from Chinese WeChat Communications
}

\author{
Jianjun Ma \\ Foreign Language College, Hunan University of Finance and Economics, Changsha, China \\ Email address: \\ majianjun@hufe.edu.cn \\ To cite this article: \\ Jianjun Ma. Cognitive Study for Language as a Complex Adaptive System: Evidence from Chinese WeChat Communications. International \\ Journal of Language and Linguistics. Vol. 7, No. 2, 2019, pp. 78-84. doi: 10.11648/j.ij11.20190702.14
}

Received: January 28, 2019; Accepted: April 23, 2019; Published: May 15, 2019

\begin{abstract}
The nature of language has always been the core issue of academic inquiry. Form and function, symbol and representation, linearity and system, static and dynamic, inner and outer, mind and brain, etc. are always the hot arguing topics in both linguistics and philosophical fields. The complex adaptive theory argues that language understanding requires whole-hearted intelligent participation and the adaptive selection of complex systems, which is the overall response of human beings to the external world and language stimulus. In order to prove this, this article chooses Chinese daily language on the WeChat as examples so as to provide evidence for explaining the complexity of language expression and language understanding. With thoughtful analysis and discussion by exploring the essential features of language evidence, this paper concludes that language understanding goes beyond the syntactic sequences of words and involves the whole cognition and adaptation of human being to the environment; semantic generation needs to mobilize the comprehensive coordination of all elements of human cognitive systems to produce the overall effect. It further indicates that thinking is literal and coherent, and suitable for logical modeling. This conclusion is in accordance with the biological and neural science claim by the second generation of cognitive science.
\end{abstract}

Keywords: Language, Complex Adaptive System, Cognition

\section{Introduction}

Language, as a symbol system that distinguishes human beings from animals, plays an immeasurable role in human civilization and evolution. It is their awareness and thinking that make human beings as human beings, while language acts as a tool and medium for human beings to perceive the objective world and communicate cultural information as a carrier. [1]

Although people have different interpretations and definitions of language, there is no consensus on the nature of language. From Plato's problem, the Descartes' mnemonics, Darwin's evolution of language, to Saussure's structure of language and Chomsky's universal grammar, people have been exploring this problem continuously throughout history. Form and function, symbol and representation, linearity and system, static and dynamic, inner and outer, mind and brain all reflect different aspects of this problem. Chomsky tries to make the study of language scientific from the syntactic structure and thinks that recursion is the common feature of human language. However, reductionist analysis cannot reflect the holistic, systematic and dynamic features of language. The theory of mind and social culture reflects the relationship between the inner psychology of language and the external environment, but neglects the subjective adaptability of human beings. In recent years, that language is a complex adaptive system $[2,3]$ puts language research into a broader interdisciplinary scope, reflecting the interaction between internal and external factors, and their views have been increasingly recognized by the academic community. This paper attempts to use the theory of complex system adaptation to explain the complexity of language expression and language understanding from a cognitive perspective, in order to explore the essential features of human language and search for evidence for in-depth study of the internal mechanism of language. 


\section{Theoretical Review}

\subsection{Theory of Language Study}

Chomsky has devoted his whole life to the study of language. His universal grammar theory tries to find common features of human language through syntactic analysis. His composition analysis method contributes to computational linguistics. "Innateness" and "universal grammar" (UG) are the main representative viewpoints. "Deep structure" and "surface structure", "I-language" and "E-language" and "minimalist program" reflect Chomsky's thinking and achievements on language theory in different periods.

After decades of development, Chomsky's theory has also spawned some new theories, such as Alvin Liberman's "motor theory". Other theories proposed by linguists and anthropologists are "body language theory", "big brain theory" and "social complexity theory". William Stokoe's "Language Origins" also claims to fill the gaps in Chomsky's "syntactic structure" in an attempt to provide evidence for Chomsky's theoretical edifice. [4]

But his theory has also been questioned and challenged, such as Pinker and Shi Yuzhi on its school of controversy. Wolfe [4] quotes Everett as arguing that the Chomsky myth has been shattered because of Chomsky's universal grammar doctrine that people have wasted half a century. He also quoted Colapinto and psychologist Michael Tomasello, noting that "universal grammar is dead" because it turned out that his theory was wrong. Chomsky himself acknowledged that the origin and evolution of human language ability are still largely a mystery. [4, 5] In recent years, Chomsky theory has been shifting from "rationalism to biolinguistics". [6]

As an emerging discipline, biolinguistics studies the biological properties of language and the evolution of language. [7] Lyle Jenkins argues that the core of biolinguistics is "the nature of language knowledge, the development of children's language, and the evolution of human language".[8] As a complex system, the evolution of language is influenced by "genetic inheritance, experience and the principle of non-linguistic competence" (ibid). For example, studies have shown that FOXP2 gene is involved in language development, [9] and non-coding changes of FOXP2, ROBO1, ROBO2 and CNTNAP2 genes are associated with language impairment (LI) and developmental reading disorder (DD). [10] However, Atkinson, E. G. et al. proved that human language evolution is not dependent on a single gene. [11] This ultra micro studies of language reflects the latest research achievements of the modern biological linguistics, but its effectiveness is still in doubt, because it ignores the complex system properties of the language. Language barriers or characteristics attributed to a genetic effect, did not consider the emergence of different level factors that interact to produce effect. Therefore, the study of language needs to consider the involvement of broader social factors.

Vygotsky's sociocultural theory interprets social environment as a factor in human understanding of society, a source of personality development and a symbol of the beginning of non-classical cognitive psychology. Language is the most important psychological tool for human beings. It is not only used for social communication, but also used for self-management, planning, guiding and monitoring of their behaviors. [12]

Vygotsky tried to find a comprehensive approach to describe and explain higher psychological functions in natural scientific terms, including the recognition of brain mechanisms and their development history under specific functions, the relationship between simple behaviors and complex forms, and the social context of behavioral development. Vygotsky et al. extended the concept of interlanguage in human-environment interaction to the use of symbols and tools, and the symbol system (language, character, and number system) was created in the process of human history and changed with the level of social form and cultural development. [13]

Jesper Kallestrup's theory of semantic externalities explores the influence of human social system and physical environment on language and mind from the perspective of philosophy of mind and philosophy of language. Semantic internalism holds that meaning, or at least some aspects of meaning, depends only on the speaker's internal psychology and is not sensitive to the relevant variables of the external environment. But semantic externalism emphasizes that the meaning of natural or social terms is external and individualized. "If what the speaker believes is determined by the propositions expressed by the sentences they use to express these beliefs, then not only is the meaning of the language individualized, but the content of their beliefs is also individualized." [14] Therefore, the understanding of the meaning of language is subject to individual subjectivity. What the speaker and listener want to express and understand is related to individual experience and judgment.

\subsection{Adaptability of Complex Systems of Language}

On March 1-3, 2007, the 60th annual conference of "Language Learning" was held at the University of Michigan. The theme was "Language is a Complex Adaptive System", and participants were asked to submit articles around the topic. The basic idea is:

Language has basic social functions. People interact with the domain-general cognitive process to form language structures and knowledge. Research in cognitive science shows that patterns of use strongly influence how language is learned, used and changed. As a complex adaptive system, language has several key features:

A The system is composed of agents (speakers in the speech community) interacting with each other;

B The system is adaptive, that is, the speaker's behavior is based on their past interactions. Current and past interactions feed back to future behaviors;

C The speaker's behavior is the result of competitive factors such as perceptual constraint and social motivation;

D Language structure is generated from the interrelated patterns of experience, social interaction and cognitive 
processes.

The complex adaptive system approach reveals the commonalities in many areas of language research, including monolingual and second language acquisition, historical linguistics, psycholinguistics, language evolution and computational models. [3]

Complex adaptive systems can uniformly explain seemingly unrelated linguistic phenomena. Wang Shiyuan [2] proved that language is a complex adaptive system from two aspects: tone change vs. ambiguity and grammar vs. ambiguity. For example, the use of intonation to distinguish words to make up for missing consonant strings in the adjustment process of ancient phonetic system may be a manifestation of dynamic adaptation system adjustment. In ancient Chinese, the substitution of this tone for consonant strings was a dynamic and systematic phenomenon. Mr. Wang Shiyuan borrowed from the ambiguity of Mr. Zhao Yuanren's famous "Ji Bu Chi Le." (means "Chicken do not eat." or "Chicken would not be eaten" ) and the English phrase "I saw her duck." ("Duck" means the poultry duck or run away). The prevalence of ambiguity of the word duck and lattice ambiguity of her indicate the complex adaptability of language. The use of phonological ambiguity and grammatical ambiguity to explain language is a complex adaptation system with empirical effects, but the complex adaptability of language is far more than that, and language understanding involves in more other complicated language phenomena.

\section{Case Analysis of Complex Adaptability of Language}

The interpretation of the internal meaning of language communication cannot be understood correctly from literal analysis. However, the ingenious pragmatics can achieve the effect that is hard to be achieved by literal words. The flexibility and creativity of pragmatics exactly reflect the complex adaptability of language, which is also the root cause of the vivid, lively and difficult simulation of real language.

\subsection{Different Understandings of the Same Happenings}

\section{Example 1:}

Last year, the WeChat group sent this message:

Another Trump rant: in another 42 days, China is stuck with what western media and pessimistic economists have predicted: factories closed, shops closed, the government shut down and the stock market closed. The rich take their families overseas, and local people are eager to exchange their money for food. Many families put up signs at their doorways to express their demands. The streets are filled with the smell of explosive residue.

The Chinese foreign ministry replied: Go away, this is the Chinese New Year (Spring Festival).

Language is a reflection of the world, but it is a subjective not a passive one. Although it is a kind of joking speech, it reflects the hostile attitude of the western media towards China, and interprets the traditional and lively Chinese New Year celebration as the economic crisis they hope, so as to satisfy their psychology of schadenfreude.

Example 2:

A student's ridiculous answer to his homework: Explain and describe the author's psychology at the time.

A classic Chinese poem: Jing Ye Si by famous poet Li Bai:

"Chuang Qian Ming Yue Guang, Yi Shi Di Shang Shuang. Ju Tou Wang Ming Yue, Di Tou Si Gu Xiang.,

A Tranquil Night

"Before my bed a pool of light, I wonder if it's frost aground. Looking up, I find the moon bright, Bowing, in homesickness I'm drowned." (Traslated by Xu Yuanchong).

But the student's ridiculous answer to this poem is :

A girl called Bright Moon took off all her clothes in front of Li Bai by the bed, her skin is as white as the frost snow in winter. Li Bai looked at the Bright Moon girl for a long time, embarrassed to think of the hometown's wife! The poem describes the poet's ambivalence about chasing girls outside.

Teacher's comment: You can graduate! Zero!

This is a quote from WeChat. According to his interpretation of $\mathrm{Li}$ Bai's poem, the student distorted the beautiful words in Li Bai's "Tranquil Night" from his own dark psychology without experiencing the poet's homesickness on a moonlight night. The same words produced different effects in different people.

Example 3:

What is the generation gap?

Generation Gap 1:

You just put on your new clothes and walk around in front of Mom and say, Mom, "You Fan Ma? "(means "Is it beautiful?") Mom took a look and said: "You, Zai Guo Li. Ni Zi Ji Tian." (means: Yes, in the pot, you add yourself...) The mother mistook "Fan"(means: fashion or beautiful)as "Fan" (means: rice).

Generation Gap 2

Daughter: Ba Ba, Ni You Wei Xin Ma? (Dad, do you have WeChat?)

Father: You Pi Wei Xin, Dou Shi Ni Ma Shuo Le Suan. (No authority at all. Your mother calls the shots.)

The father mistook his daughter words Wei Xin (WeChat) as Wei Xin (authority).

Generation Gap 3

Grandson said to Grandma: Nai Nai, Ni Hui Xia Zai Ma? (Grandma, can you download it?)

Grandma got angry: Wo Bu Hui Xia Zai, Ni Ba Ba Na Lai $D e$ ? (If I was not able to give birth, where did your father come from?)

In Chinese, Xia Zai can be understood as a phrase as "download from the internet" or as a phrase as "giving birth" in local dialect.

This kind of discourse misunderstanding is not only caused by the factors such as values, mental state and living habits of the two generations, but also by the different contexts in which the existing knowledge and experiences of the listeners and the speakers already formed in mind. The same 
or similar sounds activate the existing knowledge inventory in the brain, and come up with the understanding in accordance with their own experience, which is the main cause and common phenomenon of misunderstanding.

\subsection{Multiple Images of the Same Representation}

Example 4:

Learn 10 English words by heart today

(1). Jing Ji (economy) Yi Kao Nong Min (depends on farmers);

(2). Hai Guan (custom) Ka Si Ta Men (stuck them).

(3). Di Zhu (landlord) Lan De Lao Dong (lazy to work).

(4). Xiong Xin (ambition) An Bi Sheng (I must win) .

(5). Qiang Zhuang (strong) Si Zhuang (really strong).

(6). Xian $M u$ (ambition) E De Ma Ya (How wonderful)

(7). Pi Qi (temper) Tai Po (too provocative).

(8). Huai Yun (pregnant) Pu Lai Ge Nan De (a man pounced on).

(9). Jiu $\mathrm{Hu}$ Che (ambulance) $\mathrm{An} \mathrm{Bu} \mathrm{Neng} \mathrm{Si} \mathrm{(I} \mathrm{can} \mathrm{not}$ die.).

(10). Lu Shi (lawyer) Lao Ya (dredge for money).

Chinese clew is not only associated with the pronunciation of English, but also with the meaning of words to some extent, which has a wonderful memory clew effect. The double superposition of sound and meaning reflects the complex adaptability of semantic expression.

Example 5:

The most difficult questions in 2016

Mr. Yang found that the goddess he had been secretly in love with for many years was actually in love with him for ages at the classmates' reunion. All sorts of feelings welled up in his mind. They talked happily at the reunion meeting. On impulse, he sent a WeChat to the goddess: "Gun Chuang Dan Ma?" (Roll sheet not?, which implies sex). Goddess reply: "Gun!" ("Roll”, which implies two meanings: OK, or Piss off.) .

Question: What does this word "Gun" ("Roll”) mean?

Additional questions:

Although Mr. Yang is a Chinese professor of a famous university in China, unexpectedly he did not understand what this "Gun!" word really means! After a few sleepless nights, he finally summoned the courage to send a WeChat to the goddess: "To my home or to your home?" Goddess reply: "Qu Ni De!" (implies two meanings: go to yours or Fuck You!)

Question 1: What does "Qu Ni De" mean?

A few days later, the goddess did not come, Mr. Yang could not help to send her another message and asked: "May I wait for you at home?" The goddess reply: "You wait!"

Question2: What does "You wait" mean?

After a few days, the goddess didn't appear yet. Mr. Yang sent her a message to the goddess: "Shall I try it at your house?" The goddess replied, "You try it!"

Question3: What does she mean "You try it?"

Mr. Yang completely collapsed, because he did not know what the goddess really meant. But he still did not want to give up, and tentatively sent her a message: "You said that I dare to try it at your house?" The goddess replied, "Don't you dare!"

Question 4: What does "Don 't you dare!" mean?

Mr. Yang lost his heart, and finally sent a message to the goddess: "I only want you a word, are you really interested in me or not?"

The goddess answer: "Zhen You Yi Si!" (means: "Yes, I am." or "You are really interesting!")

Question 5: What does "Zhen You Yi Si" mean?

Mr. Yang was enraged and sent a message back to the goddess: "You think you are a goddess! I'm just having fun with you. What the hell are you?"

The goddess replied: "Shen Me Dong Xi"(means : Damn it! or What kind of thing!)

Question 6. What does "Shen Me Dong Xi" mean?

Mr. Yang finally made a desperate decision to go to the goddess's house at night. He pressed the bell and the goddess to open the door.

Goddess answered: Ni Jin Lai Kan Wo Ru He Nong Si Ni! (You come in and you'll see how I make you die tonight!) (implies: with sex or other things.)

Question 7. How did Mr. Yang die?

Netizens comment, just one word "Roll", expressed a thousand feelings, how many years of lovesickness, all kinds of feelings welled up in their minds, all contained in this one word. It is worth thousands of gold, and expresses that human feeling is profound, deeply reflecting extensive and profound Chinese culture. But the goddess's answer also contained "go away, leave: get out!", which reflected the goddess' contradictory attitude. The latter similar answers also have two interpretations, one positive and one negative. The same word carries two meanings at the same time, which makes the reply of "goddess" to "Mr. Yang" more imaginative. Such a complex and dynamic adaptation process increases the charm of the language itself, the humor and funny taste.

\subsection{Multiple Representations of One Concept}

Example 6:

Two words confused a foreigner:

(1). When eating, one person said "Qu Fang Bian Yi Xia", the foreigner did not understand, others told him "Fang Bian" means: "go to the toilet";

(2). While toasting, another person said to the foreigner that he hoped he would be able to give him "Fang Bian" (convenience) the next time when he went abroad.

(3). On banquet, a pretty TV station host puts forward, when she is "Fang Bian" (convenient), she will try to interview a foreigner, the foreigner stunned: how can you do this when you are "Fang Bian" (go to the toilet)? The pretty host says, "Then, when you are 'Fang Bian' (convenient), I invite you to have a meal! ". The foreigner fainted!

(4). When waken up next morning, the pretty host says to him again, "Otherwise when you and me are "Fang Bian" (convenient), how about having a cup of coffee?" The foreigner fainted again and did not wake up again!

Please smile when you are convenient and make your friends laugh when it's convenient for you. 
There are five explanations for the Chinses word "Fang Bian" in Xinhua dictionary: 1. convenience: e.g. Da Kai Fang Bian Zhi Men (convenient for others). "Bei Jing De Jiao Tong Hen Fang Bian" (Beijing's traffic is very convenient.) Ba Fang Bian Liu Gei Bie Ren, Ba Kun Nan Liu Gei Zi Ji. (Leave convenience to others, leave difficulties to oneself.) 2. Make others convenience, give convenience: Fang Bian Qun Zhong (Give convenience to the masses.) 3. proper: Zhe Er Shuo Hua Bu Fang Bian. (It's not proper for us to talk here.) 4. euphemism for refusal: Shou Tou Bu Fang Bian (have little money to spare). 5. euphemism, referring to defecation: Che Ting Yi Hui Er, Da Jia Ke Yi Fang Bian. (We can park for a while for defecation.)

The understanding of this kind of polysemy must be judged by the listener in different contexts. Foreigners only know one of them, and mixing them in different contexts. This is the cause of misunderstanding. The polysemy of this word is similar to the example of Mr. Wang Shiyuan's "duck" one.

Example 7:

How many ways to call Wife in China?

A foreigner wants to learn Chinese. The first lesson he got was the ways to call wife, only one word in English. The following lists some of the ways to call wife in Chinese:

(1). qĩ zi(wife); (2). lăo po(better half); (3). tài tai(missis); (4). fü rén(madam); (5). lăo bàn(old pal); (6). ài ren (sweetheart) (7). nèi ren(my humble wife); (8). xí fü(my wife); (9). nà kǒu zi(my other half); (10). zhuō jing(my humble wife); (11). xián nèi zhù(the better half); (12). duì xiàng(marriage partner);(13). hái tā māa(children's mother); (14). hái tā niáng(children's mum); (15). nèi zù(my wife); (16). pó niáng(good wife); (17). cáo kāng(my humble wife); (18). wá tā niáng(children's mummy); (19). zǎi tā niáng(children's mum); (20). shān qū(humble wife); (21). jiàn nèi(humble wife); (22). jiàn jīng(humble wife); (23). nü rén(woman); (24). mă ž̀(sweeties); (25). zhǔ fü(housewife); (26). nü zhǔ ren(hostess); (27). cái zhèng bù zháng(finance minister); (28). jì jiăn wěi(discipline inspector); (29). hún rén(unreasonable woman); (30). niáng ž̀(lady); (31). wū li de(housewife); (32). lìng yī bàn(the other half); (33). nü dāng jiāa(hostess); (34). hún jiāa(unreasonable woman); (35). fā qü(kit fat wife); (36). tang kè(wife); (37). pó yí(wife); (38). lǐng dăo(leader)

The foreign student: Why do women have so many titles?

Teacher: Women have March 8th Women's Day, so they have 38 titles. Hearing this, the foreigner found it difficult to learn Chinese well and fled away.

Actually, there are more than 38 titles for wife in Chinese. This multi-appellation phenomenon is very common in Chinese, which indicates that the referential symbol is not fixed, but changes constantly with the difference of environment and object of use. The reason is also the result of the complex adaptation of language.

Example 8:

Chinese level 8:

Xiao Ming give a leader bribery money.

Leader: Ni Shenme Yisi? (What do you mean?)
Xiao Ming: Mei Shenme Yisi. Yisi Yisi (Nothing, just express my kindness.).

Leader: Ni Zhe Jiu Bu Gou Yisi Le. (It's not proper.)

Xiao Ming: Xiao Yisi, Xiao Yisi. (Small gift, small gift.)

Leader: Ni Zheren Zhenyou Yisi. (You are so kind.)

Xiao Ming: Qi Shi Ye Mei Biede Yisi. (Actually, it doesn't mean anything else. I do not intend to ask you to do me favor.)

Leader: Na Wo Jiu Bu Hao Yisi le. (Then I accepted it with thanks.)

Xiao Ming: Shi Wo Bu Hao Yisi. (Only a small gift.)

Question: What does "Yisi" mean?

There are twelve basic explanations for the word "Yisi" in Chinese dictionary: (1) state of mind; (2) meaning;(3) intention; (4) will; (5) look; (6) interest, interesting; (7) mood, emotion; (8) cordiality, mind; (9) extended meaning means a banquet or gift that represents the will of the heart; (10) opinions, ideas; (11) signs; (12) a symbolic gesture.

How to understand it in the specific context is totally judged by the listener's experience. This interprets the multiple effects of semantic complexity and implied meaning, making language a subtle effect that is both unintelligible and intelligible.

If you want machines to understand these languages, you can't do it with syntax and algorithms. This is the essential difference between machine and human being. Although neural network analysis is done to simulate the human brain and the mechanism of human brain to interpret data, the deep learning in artificial intelligence and the man-machine dialogue in Google Assistant cannot express the complex and subtle situations in human communication.

\section{Discussion: The Cognitive Basis of Language as Complex Adaptive Systems}

In his book Semantics and Cognition, Ray Jackendoff argues that there is duality in the relationship between language and the world, that is, language can be the abstract relationship (e-semantics) to the external language users or i-semantics in the brain/mind of language users. Therefore, describing how humans use language requires describing how humans understand the relationship between language and the world. [15]

Although the understanding of this relationship has differences in semantics and pragmatics, it is essentially the cognitive psychological interpretation of the language form system, which requires the participation of information beyond the word sequence.

In English, similar examples can also be found as following:

Example 10:

Peter: Is George a good cook?

Mary: He 's a Frenchman.

In addition to using the pronoun he refers to George, it is also necessary to add the message that all French people are 
good cooks to conclude that George is a good cook. If the cognitive system is regarded as a computing device, reasoning involves multiple representations and their relations with each other, and relevant contextual information beyond the natural language text sequence needs to be included in the calculation sequence.

The theory of complex adaptive system, which emerged in the late 20th century, provides a theoretical basis for this linguistic phenomenon. Its characteristics of uncertainty, unpredictability and non-linearity are more similar to the complex process of human understanding of nature and human beings themselves, compared with the traditional classical scientific method which is too certain and too simplified.

Understanding the complexity of human language ultimately involves delving into the human mind. Biologically, self-organizing matter splits itself into meaningful coherent patterns, and its time-dependent behavior expresses the mind itself. But how such minds fit into the physical world remains a mystery. Despite our knowledge of the chemical composition and biological functioning of individual cells in the brain, our understanding of how individual cells work in coordination with many cells is inadequate. The laws and laws of coordination between organisms and organizations are important for us to understand ourselves and the world we live in. To understand the laws of mind, some mind-body philosophers recommend studying neurons, while neuroscientists and some scientists think that mental phenomena can be explained by the interactions of nerve cells. The core of the "heart-brain-body" problem is the information, how the information structure is formed in the organism, especially in the brain, how to present the dynamics with the self-organizing paradigm.[16] This also seems to explain how the cognitive system works with complex adaptive systems.

Cognitive scientists think of the way the mind works as a computer process signals, involving abstract, arbitrary symbols. But linguistic symbols themselves are meaningful, and an English speaker "to learn the meaning of Chinese symbols, those symbols must be based on concrete objects, not other Chinese symbols". [17] John Searle's "house of Chinese" thought experiment, for example, showed that symbols do not acquire meaning only through relationships with other symbols. The computational process is not enough to be the basis of meaning, not understanding the meaning of the language symbols themselves. Searle's "philosophy of mind" and Deacon's "Teleodynamics" argue that life or mental characteristics can only be generated from higher levels of interrelationships between self-organizing processes. Wolff's linguistic determinism postulates that only people who share one language will have the same understanding of the world.[18] He believes that thought is determined by the language people speak: "language forms the way we think and determines the content we think" (p72). However, the second generation of cognitive science holds that the mind is "biological and neural, not related to symbols" [19]. So, human understanding involves something beyond symbols, which may be stored in mind, but not expressed in word.

\section{Conclusion}

Therefore, only those who speak the same language can truly understand the real meaning of the language they shared, and produce the same feeling with the words, which involves complex cognitive process. Cognitive science regards symbols as tools for thinking, and the cognitive process is similar to an algorithmic process. But thinking is abstract, and limited to consciousness. Language is not linear, and its understanding requires whole-hearted intelligent participation and the adaptive selection of complex systems, which includes the overall response of human beings to the external world and language stimulus. This can be shown in the above Chinese and English examples.

\section{Acknowledgements}

This paper was funded by the 2017 social science foundation of Hunan province "Research on Dynamic System Theory and Development of Second Language Ability" (project No. 17YBA056) and the scientific project of Hunan provincial department of education "Research on the Cultivation of Comprehensive New Foreign Language Ability of Local Undergraduate Students in the Context of Educational Informatization" (project No. XJK18CGD013).

\section{References}

[1] Xu Guozhang. 1999. On Language by Xu Guozhang. Beijing: Foreign Language Teaching and Research Publishing House.

[2] Wang, Shiyuan. 2006. Language is Complex Adaptive System. Journal of Tsinghua University, 21(6): 5-13.

[3] Ellis, N. C. \& D. Larsen-Freeman. 2009. Language as a Complex Adaptive System: Position Paper. Language Learning 59: Suppl. 1. pp. v-vii.

[4] Wolfe, T. 2016. The Kingdom of Speech. New York: Little, Brown and Company, Hachette Book Group, Inc.

[5] Bolhuis, J. J., Tattersall, I., Chomsky, N. \& R. C. Berwick. 2014. How could language have evolved?. PLOS Biology, 12(8): 1-6.

[6] Chomsky, N. 2009. Cartesian Linguistics: A Chapter in the History of Rationalist Thought (3rd ed.). Cambridge: Cambridge University Press.

[7] Berwick, R. C. \& N. Chomsky. 2016. Why Only Us: Language and Evolution. Cambridge, MA: The MIT Press.

[8] Yang Kun \& Jiang Canzhong. 2017. Biolinguisitics in China-Report on the First Seminar of Biolinguistics. Foreign Language Research. (2): 127.

[9] Lai, C. S., Fisher, S. E., Hurst, J. A., Vargha-Khadem, F., \& Monaco, A. P. 2001. A fork head-domain gene is mutated in a severe speech and language disorder. Nature, 413, 519523 . 
[10] Mozzi, A. et al. 2016. The evolutionary history of genes involved in spoken and written language: beyond FOXP2. Scientific Reports 6: 1-12.

[11] Atkinson, E. G. et al. 2018. No Evidence for Recent Selection at FOXP2 among Diverse Human Populations. Cell 174, 1-12.

[12] Hall, M. J. (Trans.). 1999. The Collected Works of L. S. Vygotsky Vol. 6 Scientific Legacy. New York: Kluwer Academic/Plenum Publishers.

[13] Cole, M., John-Steiner, V., Scribner, S. \& E. Souberman. 1978. Mind in Society: The Development of Higher Psychological Processes. Cambridge: Harvard University Press.

[14] Kallestrup, J. 2012. Semantic Externalism. New York: Routledge.
[15] Lappin, S. 1996. The Handbook of Contemporary Semantic Theory. Oxford: Blackwell Publishers Ltd.

[16] Kelso, J. A. Scott.1995. Dynamic Patterns: The Self-organization of Brain and Behavior . Massachusetts: MIT Press.

[17] Shapiro, L. 2011. Embodied Cognition. New York: Routledge, Taylor \& Francis Group.

[18] Whorf, B. 1956. Language, Thought and Reality: Selected Writings of Benjamin Lee Whorf, J. Carroll (ed.) Cambridge: MIT Press.

[19] Lakoff, G. 2003. "How the Body Shapes Thought: Thinking with an All Too Human Brain". in A. Sanford and P. Johnson-Laird (eds.) The Nature and Limits of Human Understanding: The 2001 Gifford Lectures at the University of Glasgow . Edinburgh: T. \& T. Clark Publishers, Ltd.: 49-74. 